\title{
Study of the correlation between $G H$ gene polymorphism and growth traits in sheep
}

\author{
J.L. Jia, L.P. Zhang, J.P. Wu, Z.J. Ha and W.W. Li \\ Key Laboratory of Animal Genetics and Breeding, \\ College of Animal Science and Technology, \\ Gansu Agricultural University, Lanzhou, Gansu, China \\ Corresponding author: L.P. Zhang \\ E-mail: zhangliping@gsau.edu.cn
}

Genet. Mol. Res. 13 (3): 7190-7200 (2014)

Received November 22, 2013

Accepted April 11, 2014

Published September 5, 2014

DOI http://dx.doi.org/10.4238/2014.September.5.5

\begin{abstract}
The growth hormone gene plays an important role in the physiological function of an organism. The current study aimed to investigate the correlation between polymorphisms in the $5^{\prime}$ regulatory region, exon 4 , and $3^{\prime}$ untranslated region (UTR) of the sheep $G H$ gene and sheep growth traits. The DNA from 510 adult sheep was analyzed by DNA sequencing and polymerase chain reaction single-strand conformation polymorphism. Two alleles ( $\mathrm{A}$ and $\mathrm{B}$ ) and 3 genotypes $(\mathrm{AA}, \mathrm{AB}$, and $\mathrm{BB}), 2$ alleles $(\mathrm{A}$ and $\mathrm{B}$ ) and 3 genotypes $(\mathrm{AA}, \mathrm{AB}$, and $\mathrm{BB})$, and 3 alleles $(\mathrm{A}, \mathrm{B}$, and $\mathrm{C})$ and 4 genotypes (AA, $\mathrm{AB}, \mathrm{BB}$, and $\mathrm{AC})$ were found within the $5^{\prime}$ regulatory region, exon 4 , and $3^{\prime}$ UTR, respectively. In Tibetan sheep, the association analysis indicated that there were statistically significant differences in the scores of weight, length, and heart girth within the $5^{\prime}$ regulatory region; weight, length, wither height, and heart girth within exon 4; and weight, length, wither height, and heart girth within the $3^{\prime}$ UTR among the different genotypes. For exon 4, Poll Dorset sheep individuals with genotype AA showed a lower score than those of genotypes $\mathrm{BB}$ and $\mathrm{AB}(\mathrm{P}<0.05)$. With regard
\end{abstract}


to the 3' UTR, Poll Dorset sheep with genotype AC showed higher scores than those of genotypes $\mathrm{AA}$ and $\mathrm{AB}(\mathrm{P}<0.05)$.

Key words: $G H$ gene; Growth traits; Polymorphism; DNA sequencing; Polymerase chain reaction single-strand conformation polymorphism; Sheep

\section{INTRODUCTION}

Growth hormone $(\mathrm{GH})$ is single polypeptide chain protein hormone that is synthesized and secreted by the anterior pituitary eosinophils cells in vertebrates (Chen et al., 1989). The GH can accelerate metabolism and promote growth of many organs and tissues, especially the bone, muscle, and visceral organs (Ikonen et al., 2001). The $G H$ gene has a direct effect on the synthesis and secretion of GH and plays an important role in animal growth (Gadelha et al., 2012). Therefore, studies investigating the structure and function of the $G H$ gene have received increasing interest in recent years.

China is rich in sheep and goats, and the varieties in this region have many unique traits. For instance, Small Tail Han sheep have high reproductive performance and Tibetan sheep have good adaptability. These varieties are rare throughout the world. Meanwhile, China has also introduced some foreign varieties with faster growth rates and better heterosis, including the German Merino and Polled Dorset sheep. German Merino or Polled Dorset sheep make male parent and hybrid with Small Tail Han or Tibetan sheep, thus, improving sheep production in China.

Consequently, in the present study, we characterized the genetic variation of sheep $\mathrm{GH}$ gene complete sequences and investigated the correlation between genotypes and growth traits to identify suitable candidate markers that may be related to animal resistance. The results presented herein could potentially lead to the use of genetic strategies to improve sheep breeding in the future.

\section{MATERIAL AND METHODS}

Animal care and use in this study was consistent with the animal care and use requirements of Gansu Agricultural University.

\section{Samples and data collection}

The animals used in this experiment were obtained from the Huajia Sheep Breeding Farm (Dingxi, Gansu, China). We examined 510 adult sheep, including Tibetan $(\mathrm{N}=126$, ZY), Small Tail Han $(\mathrm{N}=128, \mathrm{XW})$, German Merino $(\mathrm{N}=118, \mathrm{DM})$, and Polled Dorset ( $=138$, WT) sheep.

Growth traits (i.e., weight, length, heart girth, and wither height) of experimental sheep were measured by Animal Breeding. Genomic DNA was extracted from sheep blood (jugular vein samples) by the standard phenol-chloroform extraction procedure (He et al., 2012) and quantified using a Nanodrop ND-1000 spectrophotometer (Thermo Fisher Scientific, USA). 


\section{Genotyping by polymerase chain reaction single-strand conformation polymorphism (PCR-SSCP)}

Primers were designed according to the published GH sequence for Tibetan sheep (GenBank accession No.: EF077162) (Ma et al., 2008) (Table 1). PCR analysis was conducted using a $25-\mu \mathrm{L}$ total volume reaction with $100 \mathrm{ng} / \mu \mathrm{L}$ genomic DNA, $10 \mathrm{pmol} / \mu \mathrm{L}$ of each primer, $2 \mathrm{mM}$ dNTPs, 5 U Taq DNA polymerase (TaKaRa, Dalian, China), and 10X PCR Buffer $\left(15 \mathrm{mM} \mathrm{Mg}^{2+}\right)$. The following reaction was performed using a Robocycler Gradient 96 thermocycler (Table 2). PCR products were detected via $2 \%$ agarose gel electrophoresis (Figures 1-3).

Table 1. Sequences of primers used for sequencing, polymerase chain reaction single-strand conformation polymorphism (PCR-SSCP), and quantitative PCR analysis.

\begin{tabular}{|c|c|c|c|}
\hline Primer & Primer sequence $\left(5^{\prime}-3^{\prime}\right)$ & Region & Length of products (bp) \\
\hline GH-P1 & $\begin{array}{l}\text { F AACAGGATGAGTGAGAGGAGGT } \\
\text { R CCATCATAGCTGGTGAGCTG }\end{array}$ & $5^{\prime}$ regulatory region & 210 \\
\hline GH-P2 & $\begin{array}{l}\text { F CCAGTTCACCAGACGACTCA } \\
\text { R CTGGGTGTTCTGGATGGAGTA }\end{array}$ & Exon 1, Exon 2 & 450 \\
\hline GH-P3 & $\begin{array}{l}\text { F GCACAGCACCTGCATCAACT } \\
\text { R GATGGTTTCGGAGAAGCAGA }\end{array}$ & Exon 3 & 340 \\
\hline GH-E4 & $\begin{array}{l}\text { F GGACTTGGAGCTGCTTCGCAT } \\
\text { R GGAAGGGACCCAACAATGCCA }\end{array}$ & Exon 4 & 191 \\
\hline GH-P5 & $\begin{array}{l}\text { F AGCAGAGTCTTCACCAACAGC } \\
\text { R TAGTTCTTGAGCAGCGCATC }\end{array}$ & Exon 5 & 480 \\
\hline GH-P6 & $\begin{array}{l}\text { F GGCAGGAGCTGGAAGATGTC } \\
\text { R CCTACTCAGACAATGTGATGCAA }\end{array}$ & 3' UTR & 320 \\
\hline
\end{tabular}

\begin{tabular}{|c|c|c|c|c|c|c|}
\hline Primer & Pre-denaturalization & Denaturalization & Annealing & Extension & Cycles & Extension \\
\hline GH-P1 & $94.0^{\circ} \mathrm{C}, 5 \mathrm{~min}$ & $94.0^{\circ} \mathrm{C}, 30 \mathrm{~s}$ & $62.5^{\circ} \mathrm{C}, 30 \mathrm{~s}$ & $72.0^{\circ} \mathrm{C}, 30 \mathrm{~s}$ & 30 & $72.0^{\circ} \mathrm{C}, 7 \mathrm{~min}$ \\
\hline GH-P2 & $94.0^{\circ} \mathrm{C}, 5 \mathrm{~min}$ & $94.0^{\circ} \mathrm{C}, 30 \mathrm{~s}$ & $62.4^{\circ} \mathrm{C}, 30 \mathrm{~s}$ & $72.0^{\circ} \mathrm{C}, 45 \mathrm{~s}$ & 32 & $72.0^{\circ} \mathrm{C}, 10 \mathrm{~min}$ \\
\hline GH-P3 & $94.0^{\circ} \mathrm{C}, 5 \mathrm{~min}$ & $94.0^{\circ} \mathrm{C}, 30 \mathrm{~s}$ & $59.5^{\circ} \mathrm{C}, 30 \mathrm{~s}$ & $72.0^{\circ} \mathrm{C}, 45 \mathrm{~s}$ & 30 & $72.0^{\circ} \mathrm{C}, 7 \mathrm{~min}$ \\
\hline GH-P4 & $94.0^{\circ} \mathrm{C}, 5 \mathrm{~min}$ & $94.0^{\circ} \mathrm{C}, 30 \mathrm{~s}$ & $60.0^{\circ} \mathrm{C}, 30 \mathrm{~s}$ & $72.0^{\circ} \mathrm{C}, 30 \mathrm{~s}$ & 30 & $72.0^{\circ} \mathrm{C}, 7 \mathrm{~min}$ \\
\hline GH-P5 & $94.0^{\circ} \mathrm{C}, 5 \mathrm{~min}$ & $94.0^{\circ} \mathrm{C}, 30 \mathrm{~s}$ & $62.0^{\circ} \mathrm{C}, 30 \mathrm{~s}$ & $72.0^{\circ} \mathrm{C}, 45 \mathrm{~s}$ & 35 & $72.0^{\circ} \mathrm{C}, 7 \mathrm{~min}$ \\
\hline GH-P6 & $94.0^{\circ} \mathrm{C}, 5 \mathrm{~min}$ & $94.0^{\circ} \mathrm{C}, 30 \mathrm{~s}$ & $59.5^{\circ} \mathrm{C}, 30 \mathrm{~s}$ & $72.0^{\circ} \mathrm{C}, 30 \mathrm{~s}$ & 30 & $72.0^{\circ} \mathrm{C}, 7 \mathrm{~min}$ \\
\hline
\end{tabular}

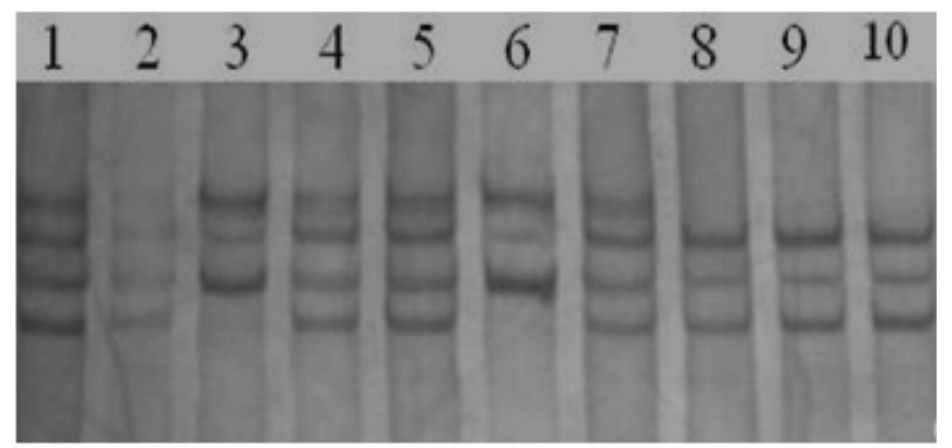

Figure 1. Agarose gel electrophoresis of GH-P1 PCR-SSCP. Lanes 1, 2, 4, 5, and 7 = genotype AB; lanes 3 and 6 $=$ genotype $\mathrm{BB}$; lanes 8,9 , and $10=$ genotype AA. 


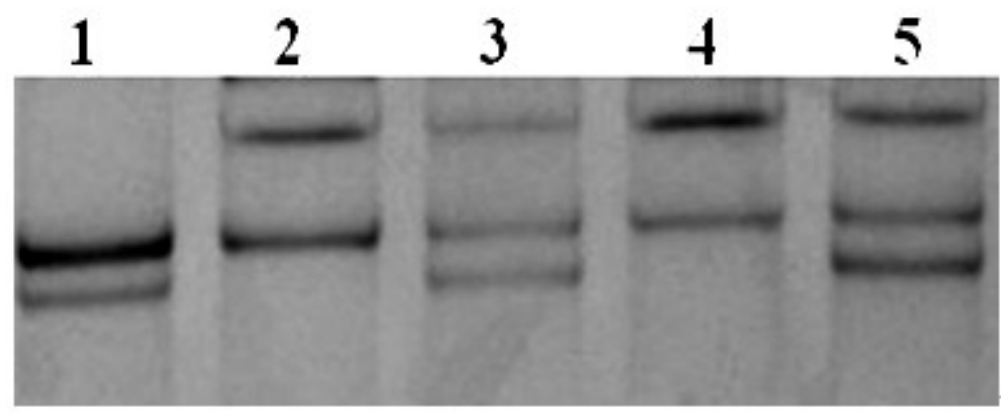

Figure 2. Agarose gel electrophoresis of GH-E4 PCR-SSCP. Lane $1=$ genotype AA; lanes 2 and 4 = genotype BB; lanes 3 and 5 = genotype $\mathrm{AB}$.

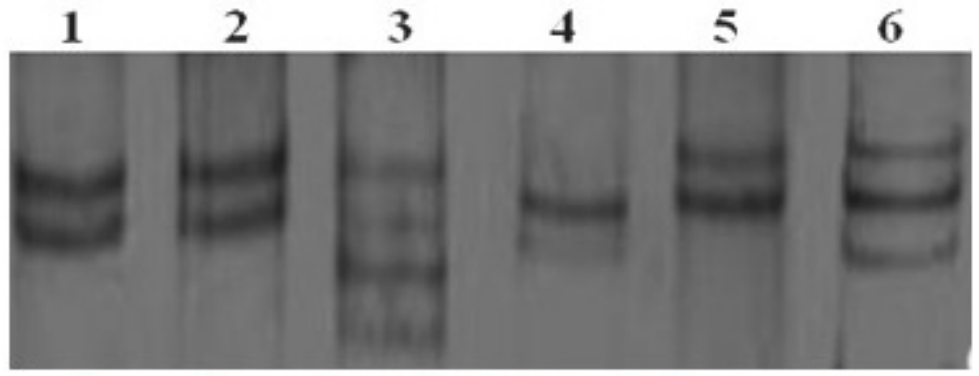

Figure 3. Agarose gel electrophoresis of GH-P6 PCR-SSCP. Lanes 1, 2 and $5=$ genotype AA; lane $3=$ genotype $\mathrm{AC}$; lane 4 = genotype $\mathrm{BB}$; lane 6 = genotype $\mathrm{AB}$.

The amplified region polymorphism of all samples was screened for by SSCP. A $2-\mu \mathrm{L}$ volume PCR product was mixed with $8 \mu \mathrm{L}$ denaturing solution ( $98 \%$ formamide, $0.025 \%$ bromophenol blue, $0.025 \%$ xylene cyanole, and $10 \mathrm{mM}$ EDTA). Denatured DNA samples were placed on $7 \times 7 \mathrm{~cm}, 14 \%$ acrylamide:bisacrylamide (29:1) gels. Electrophoresis was run at 15 $\mathrm{h}(180 \mathrm{~V})$ with constant incubation. Gels were silver-stained according to the method of Byun et al. (2009).

The polymorphic regions were sequenced by Shanghai Biological Engineering Co. (Shanghai, China; Figures 4-6).

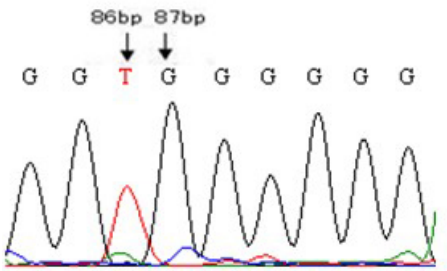

AA

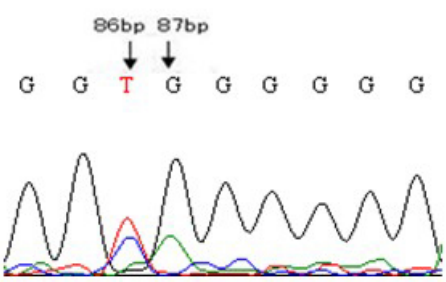

$\mathrm{AB}$

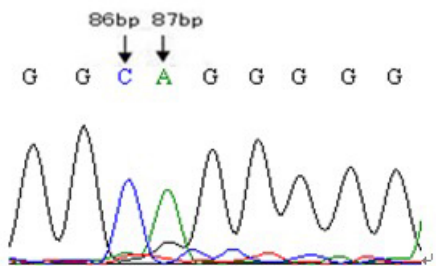

BB

Figure 4. Sequencing map GH-P1. 


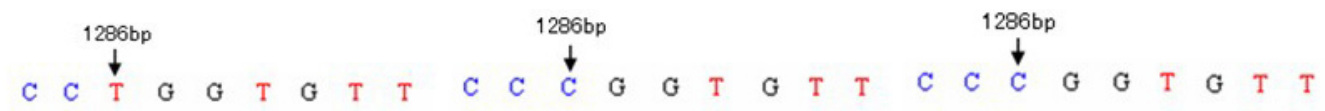

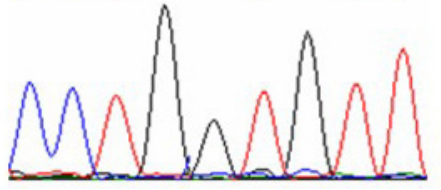

AA

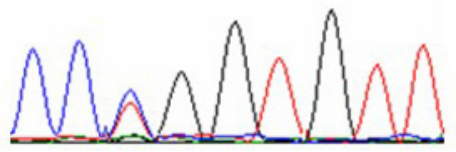

$\mathrm{AB}$

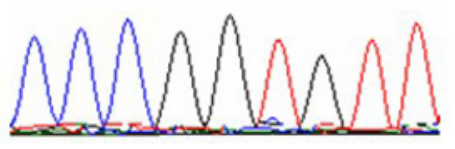

$\mathrm{BB}$

Figure 5. Sequencing map of GH-E4.

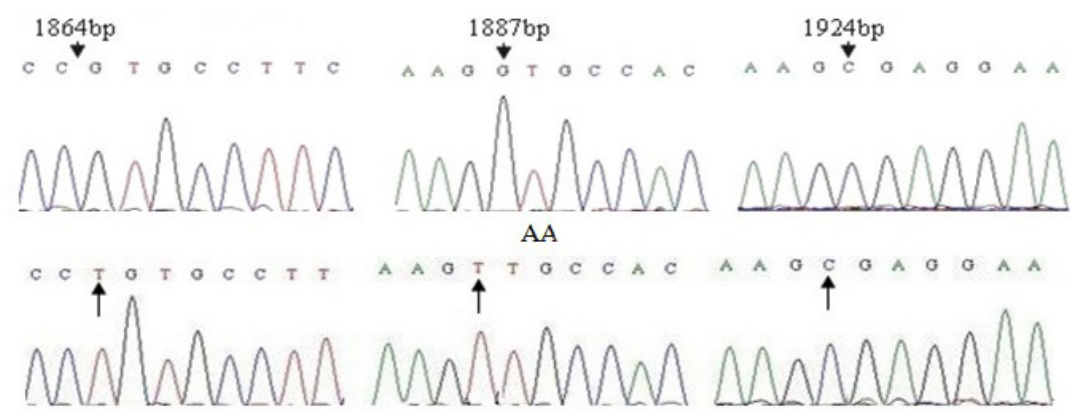

BB

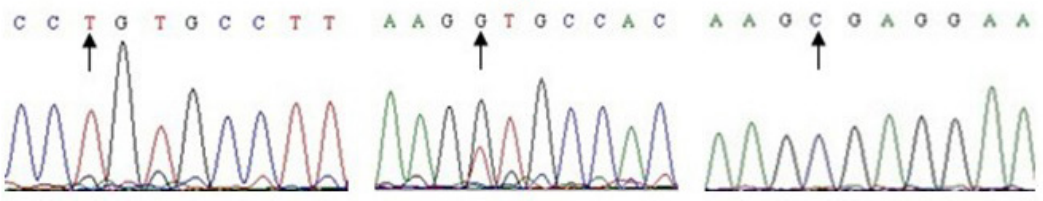

$\mathrm{AB}$

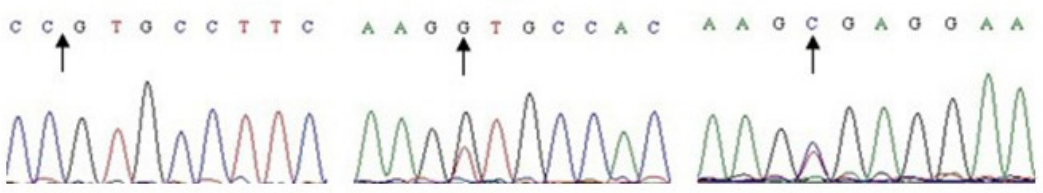

$\mathrm{AC}$

Figure 6. Sequencing map of GH-P6.

\section{Statistical analysis}

Sequence alignment, translation, and comparisons were performed using MEGA5 (Tamura et al., 2011). Genotype and allele frequencies, gene heterozygosity $\left(H_{\mathrm{E}}\right)$, polymorphism information content (PIC), and testing for deviation from Hardy-Weinberg equilibrium were calculated by POPGENE version 1.32 (Yeh et al., 1997).

The effects of genotype on sheep growth traits (i.e., weight, length, height, and girth) were estimated using the general linear model (GLM) procedure of the SAS software (SAS, 1999) according to the following statistical model: 


$$
Y_{i j k}=\mu+\alpha_{i}+\beta_{j}+\gamma_{i j}+\varepsilon_{i j k},
$$

where $i=1, \cdots, \mathrm{a} ; j=1, \cdots, \mathrm{b} ; k=1, \cdots, \mathrm{n} ; \gamma_{\mathrm{ij}}$ was interaction effect, and $\varepsilon_{\mathrm{ijk}}$ was the random residual effect.

Our model was $Y=\mu+B+G+G \times B+e$ where $Y$ was the value of the trait measured, $\mu$ was the population mean, $\mathrm{G}$ was the genotype effect, $\mathrm{B}$ was the group effect, $\mathrm{G} \times \mathrm{B}$ was the interaction effect for genotypes and groups, and e was the random residual effect. Preliminary analysis also included the fixed interaction effects of breed, genotype, and growth traits; however, these interaction effects were subsequently removed because they did not have significant effects.

\section{RESULTS}

\section{Polymorphism analysis of the $G H$ gene}

Polymorphisms in the $G H$ gene were identified within the 5 ' regulatory region (GHP1), exon 4 (GH-E4), and the 3' UTR (GH-P6). Based on the PCR products, SSCP was used for initial screening of the samples. Three unique SSCP patterns (i.e., AA, BB, and $\mathrm{AB}$ ) and 2 mutations in $\mathrm{BB}$ genotype individuals (i.e., $\mathrm{T} \rightarrow \mathrm{C}$ at $84 \mathrm{bp}$ and $\mathrm{G} \rightarrow \mathrm{A}$ at $85 \mathrm{bp}$ ) were detected in GH-P1 (Figure 4). Three unique SSCP patterns (i.e., AA, BB, and AB) and one mutation in $\mathrm{BB}$ genotype individuals (i.e., $\mathrm{T} \rightarrow \mathrm{C}$ at $88 \mathrm{bp}$ ) were detected in GH-E4 (Figure 5). Four unique SSCP patterns (i.e., AA, BB, AB, and AC) and 3 mutations were detected in GH-P6 (B allele when compared to the A allele had a $\mathrm{T}$ nucleotide insertion at $234 \mathrm{bp}$ and a $\mathrm{G} \rightarrow \mathrm{T}$ mutation at $257 \mathrm{bp}$ ). In comparison to the $\mathrm{A}$ allele, the $\mathrm{C}$ allele had a $\mathrm{C} \rightarrow \mathrm{T}$ mutation at $294 \mathrm{bp}$ (Figure 6).

In GH-P1, AA was the dominant genotype and A was the dominant allele. The GH-P1 polymorphism was not found in the German Merino or Poll Dorset sheep (Table 3). For GHE4, BB was the dominant genotype and B was the dominant allele in Tibetan and Small Tail Han Sheep; AA was the dominant genotype and A was the dominant allele in German Merino and Poll Dorset sheep (Table 4). For GH-P6, AA was the dominant genotype and A was the dominant allele in the 4 breeds. The BB genotype was not found in German Merino or Poll Dorset sheep (Table 5).

\begin{tabular}{|c|c|c|c|c|c|}
\hline \multirow[t]{2}{*}{ Breed } & \multicolumn{3}{|c|}{ Genotypes frequency } & \multicolumn{2}{|c|}{ Allele frequency } \\
\hline & AA & $\mathrm{BB}$ & $\mathrm{AB}$ & A & $\mathrm{B}$ \\
\hline $\mathrm{ZY}$ & $0.8175(103)$ & $0.0714(9)$ & $0.1111(14)$ & 0.8532 & 0.1468 \\
\hline XW & $0.6071(17)$ & $0.1071(3)$ & $0.2858(8)$ & 0.6607 & 0.3393 \\
\hline DM & $1.0000(18)$ & $0.0000(0)$ & $0.0000(0)$ & 1.0000 & 0.0000 \\
\hline WT & $1.0000(38)$ & $0.0000(0)$ & $0.0000(0)$ & 1.0000 & 0.0000 \\
\hline
\end{tabular}

\begin{tabular}{|c|c|c|c|c|c|}
\hline \multirow[t]{2}{*}{ Breed } & \multicolumn{3}{|c|}{ Genotype frequency } & \multicolumn{2}{|c|}{ Allele frequency } \\
\hline & $\mathrm{AA}$ & $\mathrm{BB}$ & $\mathrm{AB}$ & $\mathrm{A}$ & $\mathrm{B}$ \\
\hline ZY & $0.0872(11)$ & $0.6667(84)$ & $0.2461(31)$ & 0.4206 & 0.5794 \\
\hline XW & $0.1429(4)$ & 0.6071 (17) & $0.2500(7)$ & 0.4464 & 0.5536 \\
\hline DM & 0.6111 (11) & $0.2222(4)$ & 0.1667 (3) & 0.7222 & 0.2778 \\
\hline WT & $0.5263(20)$ & $0.2632(10)$ & $0.2105(8)$ & 0.6579 & 0.3421 \\
\hline
\end{tabular}




\begin{tabular}{|c|c|c|c|c|c|c|c|}
\hline \multirow[t]{2}{*}{ Breed } & \multicolumn{4}{|c|}{ Genotypes frequency } & \multicolumn{3}{|c|}{ Allele frequency } \\
\hline & $\mathrm{AA}$ & $\mathrm{AB}$ & BB & $\mathrm{AC}$ & $\mathrm{A}$ & B & $\mathrm{C}$ \\
\hline $\mathrm{ZY}$ & $0.4286(54)$ & $0.3095(39)$ & $0.1032(13)$ & $0.1578(20)$ & 0.6623 & 0.2589 & 0.0788 \\
\hline XW & $0.5357(15)$ & $0.1429(4)$ & $0.1786(5)$ & $0.1428(4)$ & 0.6786 & 0.2501 & 0.0713 \\
\hline DM & $0.2222(4)$ & $0.6111(11)$ & $0.0000(0)$ & $0.1667(3)$ & 0.6111 & 0.3056 & 0.0833 \\
\hline WT & 0.5000 (19) & $0.2895(11)$ & $0.0000(0)$ & $0.2105(8)$ & 0.6053 & 0.1447 & 0.2500 \\
\hline
\end{tabular}

For GH-P1, GH-E4, and GH-P6, significant deviations from Hardy-Weinberg equilibrium were tested for genotype distributions in the 4 sheep breeds $(\mathrm{P}<0.01)$. The PIC for the studied populations ranged from 0.2691 to 0.4864 . According to the protocol of Vaiman et al. (1994), this locus was moderately polymorphic in the 3 populations $(0.25<$ PIC $<0.50$; Table 6).

\begin{tabular}{|c|c|c|c|c|c|}
\hline Locus & Breed & $H_{\mathrm{o}}$ & $H_{\mathrm{E}}$ & $N_{\mathrm{E}}$ & PIC \\
\hline \multirow[t]{4}{*}{ GH-P1 } & $\mathrm{ZY}$ & 0.7495 & 0.2505 & 1.3342 & 0.3691 \\
\hline & XW & 0.5516 & 0.4484 & 1.8127 & 0.3478 \\
\hline & DM & 1.0000 & 0.0000 & 1.0000 & 0.0000 \\
\hline & WT & 1.0000 & 0.0000 & 1.0000 & 0.0000 \\
\hline \multirow[t]{4}{*}{ GH-E4 } & ZY & 0.5126 & 0.4874 & 1.9508 & 0.3686 \\
\hline & XW & 0.5057 & 0.4943 & 1.9773 & 0.3721 \\
\hline & DM & 0.5987 & 0.4013 & 1.6702 & 0.3208 \\
\hline & WT & 0.5499 & 0.4501 & 1.8186 & 0.3488 \\
\hline \multirow[t]{4}{*}{ GH-P6 } & ZY & 0.5119 & 0.4881 & 1.9536 & 0.4230 \\
\hline & XW & 0.5281 & 0.4719 & 1.8935 & 0.4089 \\
\hline & DM & 0.7438 & 0.5262 & 2.1107 & 0.4499 \\
\hline & WT & 0.4498 & 0.5502 & 2.2231 & 0.4864 \\
\hline
\end{tabular}

The nucleotide characterizations of these polymorphisms were revealed by DNA sequencing. A comparison with previously identified alleles indicated that new mutations (c. $1268 \mathrm{~T} \rightarrow \mathrm{C}$ ) were found for the first time in sheep. The new allele sequences have been deposited in the GenBank database (http://www.ncbi.nlm.nih.gov/nuccore/) under accession No. EF077162.

\section{Correlation between the $G H$ gene polymorphisms and growth traits}

With regard to the 5 ' regulatory region, the statistical results showed that a significantly different locus was observed between the effects of genotype and growth traits in Tibetan sheep $(\mathrm{P}<0.05)$. The least square means along with the standard errors for growth trait scores among the different genotypes are given in Table 7 . The genotypic linear contrasts suggest that growth trait scores for the AA genotype were significantly lower than those for genotypes $\mathrm{AB}$ and $\mathrm{BB}(\mathrm{P}<0.05)$. There were no significant differences in genotype effect and growth traits in Small Tail Han sheep $(\mathrm{P}>0.05)$. Polymorphisms were not detected for the German Merino or Poll Dorset sheep. The results were the same as Komisarek et al. (2011), Wang et al. (2012), Min et al. (2005), and Gao (2004). 
Table 7. Correlation analysis for the $G H$ gene and growth traits in GH-P1.

\begin{tabular}{llccrr}
\hline Breed & Genotype & Weight & Length & Height & Heart girth \\
\hline ZY & AA $(\mathrm{N}=103)$ & $55.1760 \pm 1.2712^{\mathrm{B}}$ & $71.0100 \pm 0.4334^{\mathrm{B}}$ & $73.1840 \pm 0.5850^{\mathrm{B}}$ & $97.7570 \pm 0.9987^{\mathrm{B}}$ \\
& AB $(\mathrm{N}=14)$ & $69.8210 \pm 1.7994^{\mathrm{A}}$ & $75.5000 \pm 1.1180^{\mathrm{A}}$ & $77.7860 \pm 1.4188^{\mathrm{A}}$ & $106.2100 \pm 1.0227^{\mathrm{A}}$ \\
& BB $(\mathrm{N}=9)$ & $70.8330 \pm 2.7821^{\mathrm{A}}$ & $74.6670 \pm 0.9574^{\mathrm{A}}$ & $81.4440 \pm 1.1194^{\mathrm{A}}$ & $106.3300 \pm 2.1344^{\mathrm{A}}$ \\
XW & AA $(\mathrm{N}=17)$ & $60.9410 \pm 2.5516^{\mathrm{A}}$ & $78.8240 \pm 0.9125^{\mathrm{A}}$ & $77.3530 \pm 1.4576^{\mathrm{A}}$ & $84.6470 \pm 1.4968^{\mathrm{A}}$ \\
& AB $(\mathrm{N}=8)$ & $61.8750 \pm 3.6520^{\mathrm{A}}$ & $77.1250 \pm 1.3016^{\mathrm{A}}$ & $74.7500 \pm 2.0938^{\mathrm{A}}$ & $85.3750 \pm 2.4996^{\mathrm{A}}$ \\
& BB $(\mathrm{N}=3)$ & $66.6670 \pm 1.6667^{\mathrm{A}}$ & $81.6670 \pm 1.7638^{\mathrm{A}}$ & $80.6670 \pm 3.4801^{\mathrm{A}}$ & $88.6670 \pm 1.7638^{\mathrm{A}}$ \\
\hline
\end{tabular}

Trait values followed by different superscript letters indicate significance $(\mathrm{P}<0.05)$.

At Exon 4, the statistical results showed that a significantly different locus was observed between the effects of genotype and growth traits in Tibetan and Poll Dorset sheep $(\mathrm{P}<0.05)$. The least square means along with the standard errors for growth trait scores among the different genotypes are given in Table 8 . The genotypic linear contrasts suggest that the growth trait scores of genotypes $\mathrm{BB}$ were significantly greater than those of genotypes AA and AB in Tibetan sheep, and growth trait scores of genotype AA were significantly lower than those of genotypes $A B$ and $B B$ in Poll Dorset sheep $(P<0.05)$. There were no significant differences in genotype effect and growth traits in Small Tail Han or German Merino sheep $(\mathrm{P}>0.05)$.

Table 8. Correlation analysis for the $G H$ gene and growth traits in E4.

\begin{tabular}{llccrr}
\hline Breed & Genotype & Weight & Length & Height & \multicolumn{1}{c}{ Heart girth } \\
\hline ZY & AA $(\mathrm{N}=11)$ & $40.9670 \pm 2.3081^{\mathrm{B}}$ & $69.4670 \pm 1.7344^{\mathrm{B}}$ & $70.8670 \pm 1.1583^{\mathrm{B}}$ & $90.6000 \pm 2.3275^{\mathrm{B}}$ \\
& AB $(\mathrm{N}=31)$ & $44.6750 \pm 2.5689^{\mathrm{B}}$ & $69.0000 \pm 1.1562^{\mathrm{B}}$ & $70.9000 \pm 1.2647^{\mathrm{B}}$ & $88.9000 \pm 2.6025^{\mathrm{B}}$ \\
& BB $(\mathrm{N}=84)$ & $63.6270 \pm 0.9636^{\mathrm{A}}$ & $76.2420 \pm 0.5430^{\mathrm{A}}$ & $74.3740 \pm 0.3766^{\mathrm{A}}$ & $103.0300 \pm 0.7075^{\mathrm{A}}$ \\
XW & AA $(\mathrm{N}=4)$ & $54.0000 \pm 1.8708^{\mathrm{A}}$ & $74.4000 \pm 3.2650^{\mathrm{A}}$ & $76.2000 \pm 0.5831^{\mathrm{A}}$ & $86.5000 \pm 3.6125^{\mathrm{A}}$ \\
& AB $(\mathrm{N}=7)$ & $54.3333 \pm 2.5386^{\mathrm{A}}$ & $74.8333 \pm 1.4472^{\mathrm{A}}$ & $76.5000 \pm 0.4282^{\mathrm{A}}$ & $83.7500 \pm 1.4592^{\mathrm{A}}$ \\
& BB $(\mathrm{N}=17)$ & $56.7650 \pm 2.1837^{\mathrm{A}}$ & $78.4710 \pm 1.4905^{\mathrm{A}}$ & $80.1180 \pm 1.0142^{\mathrm{A}}$ & $88.4710 \pm 1.4706^{\mathrm{A}}$ \\
DM & AA $(\mathrm{N}=11)$ & $55.6400 \pm 3.1739^{\mathrm{A}}$ & $66.4000 \pm 0.9713^{\mathrm{A}}$ & $65.9000 \pm 0.6658^{\mathrm{A}}$ & $93.3333 \pm 2.2964^{\mathrm{A}}$ \\
& AB $(\mathrm{N}=3)$ & $46.5333 \pm 1.1392^{\mathrm{A}}$ & $63.3333 \pm 0.6667^{\mathrm{A}}$ & $64.0000 \pm 0.5774^{\mathrm{A}}$ & $85.6667 \pm 1.4530^{\mathrm{A}}$ \\
& BB $(\mathrm{N}=4)$ & $50.2400 \pm 2.3112^{\mathrm{A}}$ & $68.2000 \pm 1.4714^{\mathrm{A}}$ & $66.5000 \pm 1.1937^{\mathrm{A}}$ & $89.3568 \pm 1.8138^{\mathrm{A}}$ \\
WT & AA $(\mathrm{N}=20)$ & $102.2600 \pm 2.3073^{\mathrm{B}}$ & $72.7890 \pm 1.2741^{\mathrm{B}}$ & $66.4210 \pm 0.8696^{\mathrm{B}}$ & $91.4210 \pm 1.3665^{\mathrm{B}}$ \\
& AB $(\mathrm{N}=8)$ & $140.1111 \pm 6.1293^{\mathrm{A}}$ & $80.6667 \pm 3.0596^{\mathrm{A}}$ & $70.5000 \pm 1.1547^{\mathrm{A}}$ & $115.3900 \pm 3.3414^{\mathrm{A}}$ \\
& BB $(\mathrm{N}=10)$ & $128.8000 \pm 5.0767^{\mathrm{A}}$ & $80.5000 \pm 1.4776^{\mathrm{A}}$ & $70.4000 \pm 0.9911^{\mathrm{A}}$ & $113.9000 \pm 3.1392^{\mathrm{A}}$ \\
\hline
\end{tabular}

Same trait values with different superscript letters indicate significance $(\mathrm{P}<0.05)$.

At the 3' UTR, statistical results showed that a significantly different locus was observed between genotype effect and growth traits in Tibetan and Poll Dorset sheep (P $<0.05)$. The least square means and the standard errors for growth trait scores among the different genotypes are given in Table 9. The genotypic linear contrasts suggested that growth trait scores of genotypes BB were significantly lower than those of genotypes AA, $\mathrm{AB}$, and $\mathrm{AC}$ in Tibetan sheep, and growth trait scores of genotype $\mathrm{AC}$ were significantly greater than those of genotypes $\mathrm{AA}$ and $\mathrm{AB}$ in Poll Dorset sheep $(\mathrm{P}<0.05)$. There were no significant differences in genotype effect and growth traits in Small Tail Han or German Merino sheep $(\mathrm{P}>0.05)$. Genotype BB individuals were not detected for German Merino or Poll Dorset sheep. 
Table 9. Correlation analysis for the $G H$ gene and growth traits in GH-P6.

\begin{tabular}{|c|c|c|c|c|c|}
\hline Breed & Genotype & Weight & Length & Height & Heart girth \\
\hline \multirow[t]{4}{*}{ ZY } & $\mathrm{AA}(\mathrm{N}=54)$ & $47.4540 \pm 1.6194^{\mathrm{B}}$ & $70.6110 \pm 0.7654^{\mathrm{B}}$ & $61.8520 \pm 0.6515^{\mathrm{B}}$ & $93.2410 \pm 1.4236^{\mathrm{B}}$ \\
\hline & $\mathrm{AB}(\mathrm{N}=39)$ & $62.8970 \pm 1.1761^{\mathrm{A}}$ & $75.1030 \pm 0.7527^{\mathrm{A}}$ & $73.8460 \pm 0.5674^{\mathrm{A}}$ & $102.44000 \pm 1.0311^{\mathrm{A}}$ \\
\hline & $\mathrm{BB}(\mathrm{N}=13)$ & $68.0460 \pm 2.0894^{\mathrm{A}}$ & $76.9230 \pm 1.4609^{\mathrm{A}}$ & $74.4500 \pm 0.6976^{\mathrm{A}}$ & $104.3100 \pm 2.2571^{\mathrm{A}}$ \\
\hline & $\mathrm{AC}(\mathrm{N}=20)$ & $69.9000 \pm 1.3507^{\mathrm{A}}$ & $79.6000 \pm 1.1503^{\mathrm{A}}$ & $76.9230 \pm 1.0157^{\mathrm{A}}$ & $106.3500 \pm 1.1477^{\mathrm{A}}$ \\
\hline \multirow[t]{4}{*}{ XW } & $\mathrm{AA}(\mathrm{N}=15)$ & $60.3750 \pm 2.6487^{\mathrm{A}}$ & $77.1880 \pm 1.5417^{\mathrm{A}}$ & $78.3750 \pm 0.8459^{\mathrm{A}}$ & $87.3750 \pm 1.5669^{\mathrm{A}}$ \\
\hline & $\mathrm{AB}(\mathrm{N}=4)$ & $65.0000 \pm 2.2361^{\mathrm{A}}$ & $75.8000 \pm 1.5937^{\mathrm{A}}$ & $78.8000 \pm 2.2672^{\mathrm{A}}$ & $88.2000 \pm 1.4283^{\mathrm{A}}$ \\
\hline & $\mathrm{BB}(\mathrm{N}=5)$ & $60.0000 \pm 7.3598^{\mathrm{A}}$ & $74.7500 \pm 4.2500^{\mathrm{A}}$ & $77.2500 \pm 2.1747^{\mathrm{A}}$ & $83.5000 \pm 4.9917^{\mathrm{A}}$ \\
\hline & $\mathrm{AC}(\mathrm{N}=4)$ & $66.6667 \pm 1.6667^{\mathrm{A}}$ & $80.6667 \pm 3.4801^{\mathrm{A}}$ & $81.6667 \pm 1.7638^{\mathrm{A}}$ & $88.6667 \pm 1.7638^{\mathrm{A}}$ \\
\hline \multirow[t]{3}{*}{ DM } & $\mathrm{AA}(\mathrm{N}=4)$ & $58.1600 \pm 1.5197^{\mathrm{A}}$ & $64.7000 \pm 0.7348^{\mathrm{A}}$ & $65.4000 \pm 0.5788^{\mathrm{A}}$ & $95.7000 \pm 0.9165^{\mathrm{A}}$ \\
\hline & $\mathrm{AB}(\mathrm{N}=11)$ & $50.9140 \pm 4.5830^{\mathrm{A}}$ & $66.6430 \pm 1.4172^{\mathrm{A}}$ & $65.7140 \pm 0.9872^{\mathrm{A}}$ & $89.3750 \pm 3.2891^{\mathrm{A}}$ \\
\hline & $\mathrm{AC}(\mathrm{N}=3)$ & $50.0000 \pm 1.9023^{\mathrm{A}}$ & $67.5000 \pm 1.3904^{\mathrm{A}}$ & $66.0830 \pm 1.0600^{\mathrm{A}}$ & $88.7500 \pm 1.5798^{\mathrm{A}}$ \\
\hline \multirow[t]{3}{*}{ WT } & $\mathrm{AA}(\mathrm{N}=8)$ & $101.5000 \pm 2.8752^{\mathrm{B}}$ & $72.0000 \pm 1.4220^{\mathrm{B}}$ & $68.3000 \pm 1.2207^{\mathrm{B}}$ & $91.3000 \pm 1.8682^{\mathrm{B}}$ \\
\hline & $\mathrm{AB}(\mathrm{N}=11)$ & $112.2900 \pm 7.8479^{\mathrm{B}}$ & $76.2500 \pm 2.9468^{\mathrm{B}}$ & $68.0000 \pm 1.1871^{\mathrm{B}}$ & $95.2920 \pm 4.0248^{B}$ \\
\hline & $\mathrm{AC}(\mathrm{N}=19)$ & $132.3400 \pm 3.1714^{\mathrm{A}}$ & $88.7500 \pm 1.2764^{\mathrm{A}}$ & $80.7190 \pm 0.8391^{\mathrm{A}}$ & $114.310 \pm 2.5261^{\mathrm{A}}$ \\
\hline
\end{tabular}

Same trait values with different superscript letters indicate significance $(\mathrm{P}<0.05)$.

\section{DISCUSSION}

\section{Genetic diversity of the sheep $G H$ gene}

One of the most remarkable features of the sheep $G H$ gene is its extremely high degree of genetic polymorphism within loci. Extensive genetic studies have been conducted on the complete sequence of the $G H$ gene in various species (Ofir and Gootwine, 1997; Jiang and Zhang, 2002). Wang et al. (2002) detected ApaI polymorphism loci in the swine GH gene intron 3 and exon 5 with restriction fragment length polymorphism analysis of PCR-amplified products; these polymorphic loci indicated a correlation between $G H$ gene polymorphisms and growth traits. Gao (2004) detected the bovine $G H$ gene at intron 3, intron 4, 3' UTR, and 5' UTR with PCR-SSCP; the results showed that these polymorphic loci were correlated with growth traits.

$H_{\mathrm{E}}$ and PIC are considered suitable parameters for estimating the genetic variation of populations. High PIC is representative of poor gene consistency, high genetic variability, and great genetic potentialities. The $H_{\mathrm{E}}$ and PIC of our study was $>0.31$ in the 4 sheep breeds; these results indicate that the $G H$ gene had intermediate polymorphism $(0.25<\mathrm{PIC}<0.5)$.

\section{Correlation between the $G H$ gene and growth traits}

Previous studies have established that the $G H$ gene is related to sheep meat and goat milk performance (Marques et al., 2003; Ren et al., 2008). The GH gene directs the synthesis and secretion of the GH hormone and regulates body metabolism and growth (Liu, 2001). However, there is currently no research assessing the complete sequence of the sheep $G H$ gene and its effects on growth traits. In the present study, we observed a statistically significant difference in the scores of growth traits between different genotypes within the 5 ' regulatory region, exon 4, and 3' UTR of the sheep $G H$ gene. In the 5' regulatory region, genotype AA of Tibetan sheep indicated lower occurrence of growth traits than those of genotypes AB and BB. This finding was in accordance with previous observations by Komisarek et al. (2011), Wang et al. (2012), and Min et al. (2005). In exon 4, genotype BB of Tibetan sheep indicated greater 
growth traits than those of genotypes AA and AB; genotype AA of German Merino sheep indicated lower growth traits than those of genotypes $\mathrm{AB}$ and $\mathrm{BB}$. These findings support those in previous observations by Bastos et al. (2001), Malveiro et al. (2001), and Zhang et al. (2008). Within the 3' UTR, genotype AA of Tibetan sheep indicated lower growth traits than those of genotypes $\mathrm{AB}, \mathrm{BB}$, and $\mathrm{AC}$; genotype $\mathrm{AC}$ of German Merino sheep indicated greater growth traits than those of genotypes $\mathrm{AB}$ and $\mathrm{BB}$. These findings provide evidence in the support of previous observations by Zhang et al. (1992) and Deng et al. (2008).

To our knowledge, this is the first report describing a significant correlation between the sheep $G H$ gene complete sequence and growth traits. The results reported herein provide a theoretical foundation for further research on sheep meat performance. Considering that sheep meat performance is influenced by multiple factors such as birth weight, age, gender, and feeding manners (in particular), further studies (e.g., sample amplification and DNA typing) are required to facilitate the future understanding of the associations between specific alleles and SNPs, which will provide more detailed information with possible applications for meat-type sheep breeding programs in the future.

\section{ACKNOWLEDGMENTS}

Research supported by the National Natural Science Foundation of China, Study of the Regulation Mechanism and Signaling Molecules of Sheep Twinning Traits Through Protein Different Expression and its Dynamic Composition (\#31260547), and Animal Husbandry Department of Gansu Province, Study of the Regulation Mechanism of Sheep Twinning Traits (\#GNSW-2012-24).

\section{REFERENCES}

Bastos E, Cravador A, Azevedo J and Guedes-Pinto H (2001). Single strand conformation polymorphism (SSCP) detection in six genes in Portuguese indigenous sheep breed "Churra da Terra Quente". Biotechnol. Agron. Soc. Environ. 5: 7-15.

Byun SO, Fang Q, Zhou H and Hickford JG (2009). An effective method for silver-staining DNA in large numbers of polyacrylamide gels. Anal. Biochem. 385: 174-175.

Chen EY, Liao YC, Smith DH, Barrera-Saldana HA, et al. (1989). The human growth hormone locus: nucleotide sequence, biology, and evolution. Genomics 4: 479-497.

Deng XS, Wan J, Chen SY, Wang Y, et al. (2008). The correlations between polymorphism of growth hormone receptor gene and butcher traits in rabbit. Yi Chuan 30: 1427-1432.

Gadelha MR, Kasuki L and Korbonits M (2012). Novel pathway for somatostatin analogs in patients with acromegaly. Trends Endocrinol. Metab. 24: 238-246.

Gao X (2004). Formatting: Study on Molecular Markers of Growth and Development in Cattle by Candidate Genes. Doctoral Thesis. Northwest Agriculture \& Forestry University, Yangling.

He R, Chang Z and Fan J (2012). Genomic DNA isolation and optimization for ISSR reaction system of Tussilago farfara L. Chin. Agr. Sci. Bull. 28: 236-241.

Ikonen T, Bovenhuis H, Ojala M, Ruottinen O, et al. (2001). Associations between casein haplotypes and first lactation milk production traits in Finnish Ayrshire cows. J. Dairy Sci. 84: 507-514.

Jiang SG and Zhang DC (2002). Molecular cloning and sequence analysis of growth hormone cDNA from Cirrhina molitorela. J. Fish. Sci. China 10: 97-101.

Komisarek J, Michalak A and Walendowska A (2011). The effects of polymorphisms in DGAT1, GH and GHR genes on reproduction and production traits in Jersey cows. Anim. Sci. Paper. Rep. 29: 29-36.

Liu S (2001). The molecular mechanism of growth hormone action. Xinjiang Agr. Sci. 1: 51-53.

Ma Z, Wei Y and Chen S (2008). Cloning and sequence analysis of Growth Hormone (GH) gene in Tibetan sheep. $J$. Northwest A\&F Univ. (Nat. Sci. Edit.) 36: 19-36.

Malveiro E, Pereira M, Marques PX, Santos IC, et al. (2001). Polymorphisms at the five exons of the growth hormone gene 
in the algarvia goat: possible association with milk traits. Small Rumin. Res. 41: 163-170.

Marques PX, Pereira M and Marques MR (2003). Association of milk traits with SSCP polymorphisms at the growth hormone gene in the Serrana goat. Small Rumin. Res. 50: 177-185.

Min LJ, Li MY, Sun GQ, Pan QJ, et al. (2005). Relationship between polymorphism of growth hormone gene and production traits in goats. Yi Chuan Xue Bao 32: 650-654.

Ofir R and Gootwine E (1997). Ovine growth hormone gene duplication-structural and evolutionary implications. Mamm. Genome 8: 770-772.

Ren CC, Wu JP, Zhang LP and Zhang HR (2008). Polymorphism of exon 4 of ovine growth hormone gene. J. Gansu Agr. Univ. 43: 12-16.

SAS (1999). (1999). SAS User's Guide: Statistics. Version 8.01. SAS Institute Inc., Cary.

Tamura K, Peterson D, Peterson N, Stecher G, et al. (2011). MEGA5: molecular evolutionary genetics analysis using maximum likelihood, evolutionary distance, and maximum parsimony methods. Mol. Biol. Evol. 28: 2731-2739.

Vaiman D, Mercier D, Moazami-Goudarzi K, Eggen A, et al. (1994). A set of 99 cattle microsatellites: characterization, synteny mapping, and polymorphism. Mamm. Genome 5: 288-297.

Wang S, Wang J, Tian S and Wang R (2012). Structure characteristics of 5'flanking region of growth hormone gene of guizhou pony and Ili horse. Guizhou Agr. Sci. 40: 151-155.

Wang WJ, Chen KF, Ren J, Ding NS, et al. (2002). Relationship of growth hormone (GH 2) genotypes with some production performances in pig. Yi Chuan Xue Bao 29: 111-114.

Yeh FC, Yang RC, Boyle T and Ye ZH (1997). POPGENE: The User-Friendly Shareware for Population Genetic Analysis. Molecular Biology and Biotechnology Centre, University of Alberta, Canada. Available at [http://www. ualberta.ca/ fyeh/]. Accessed October 4, 2001.

Zhang HM, Brown DR, Denise SK and Ax RL (1992). Nucleotide sequence determination of a bovine somatotropin allele. Anim. Genet. 23: 578.

Zhang HP, Zhang GJ, Xiang D and Liu CJ (2008). Association of PCR-RFLP at the growth hormone gene with early growth and developmental traits in the Nanjiang brown goats. Acta Vet. Zootech. Sin. 39: 423-428. 